\title{
Taxonomic review of Xenorhyncocoris Miller (Heteroptera: Reduviidae: Ectrichodiinae), with description of $X$. attractivus sp. nov. and notes on sexual dimorphism of the genus
}

\author{
Zhuo CHEN ${ }^{1}$, Yingqi $\mathrm{LIU}^{2}$ \& Wanzhi CAI ${ }^{3, *}$ \\ 1,2,3 Department of Entomology and MOA Key Lab of Pest Monitoring and Green Management, \\ College of Plant Protection, China Agricultural University, Beijing 100193, China. \\ *Corresponding author: caiwz@cau.edu.cn \\ 1Email: insectchen625@126.com \\ 2Email: yingqiliu0720@163.com \\ ${ }^{1}$ urn:1sid:zoobank.org:author:114B2A5A-3D0F-4E06-9C81-207BA77753B6
${ }^{2}$ urn:1sid:zoobank.org:author:DB34F0CC-7DC8-4BC7-8E3D-042239CA883D
${ }^{3}$ urn:1sid:zoobank.org:author:06A808A1-3AF2-46EE-AFCF-36B6F9D6DEE7
}

Abstract. The enigmatic millipede assassin bug genus Xenorhyncocoris Miller, 1938 is revised. Previously known species, X. caraboides Miller, 1938, X. princeps Miller, 1949 and X. schoenitzeri Putshkov \& Bérenger, 1999, are diagnosed and photographed. A new species, X. attractivus sp. nov., is described based on male and female specimens from northeastern Borneo. The male of Xenorhyncocoris is reported for the first time, revealing the extreme sexual dimorphism present in the genus. The diagnosis of Xenorhyncocoris is extended in order to make it applicable to the new discovery, and a female-based key to species of the genus is updated. Relationships among Xenorhyncocoris and Vilius Stål, 1863, Neozirta Distant, 1919 and Schottus Distant, 1902 are briefly discussed.

Keywords. Hemiptera, Ectrichodiini, taxonomy, new species, Oriental Region.

Chen Z., Liu Y. \& Cai W. 2021. Taxonomic review of Xenorhyncocoris Miller (Heteroptera: Reduviidae: Ectrichodiinae), with description of $X$. attractivus sp. nov. and notes on sexual dimorphism of the genus. European Journal of Taxonomy 746: 26-49. https://doi.org/10.5852/ejt.2021.746.1315

\section{Introduction}

Millipede assassin bugs have been treated as a separate subfamily Ectrichodiinae since Amyot \& Audinet-Serville (1843), but were recently reduced to the tribe Ectrichodiini based on a phylogenetic study combining morphological and molecular data (Forthman \& Weirauch 2017). This group, comprising about 670 species in 120 genera, is generally circumtropical in distribution, with only a few species reaching temperate regions (Maldonado Capriles 1990; Swanson 2019). Millipede assassin bugs are often robust-bodied and ground-dwelling, and are believed to be specialized millipede predators (Forthman \& Weirauch 2012). This charismatic group has long intrigued scientists not only because of its unique diet, but also for its ubiquitous aposematic coloration and sexual dimorphism, which are not 
common in most of the other reduviid subfamilies (Dougherty 1995; Weirauch et al. 2014; Forthman \& Weirauch 2017, 2018).

Despite the high species diversity among Ectrichodiini, many taxa of this group are described based on only a few specimens of a single sex, which, coupled with the prevalence of sexual dimorphism within the group, can sometimes cause difficulty with matching the conspecific males and females and can even cause taxonomic confusions (e.g., Rédei \& Tsai 2012; Rédei et al. 2012). Such taxonomic problems also impede our knowledge concerning the actual biodiversity and evolutionary relationships of millipede assassin bugs. Thanks to recent advances in DNA sequencing, molecular data can be effectively obtained and utilized, together with morphological and distributional information, to associate sexually dimorphic individuals and different life stages, which has already been successfully applied in Reduviidae (e.g., Zhang \& Weirauch 2011; Forthman et al. 2016; Weirauch et al. 2017).

Miller (1938) described a large-sized and bizarre-looking millipede assassin bug, Xenorhyncocoris caraboides Miller, 1938, from Sumatra. He erected the genus Xenorhyncocoris Miller, 1938 to accommodate this species, but little was known about its habitat and taxonomic relationships. An additional species, X. princeps Miller, 1949, was subsequently described from Peninsular Malaysia (Miller 1949). The most comprehensive study on Xenorhyncocoris was conducted by Putshkov \& Bérenger (1999). They described another Sumatran species, X. schoenitzeri Putshkov \& Bérenger, 1999, provided a female-based key to species of the genus, and discussed some specialized morphological characters of the genus. Nevertheless, all the three species of Xenorhyncocoris are based on single micropterous female specimens, and no further data concerning these species have been obtained since their original descriptions. Knowledge on systematic relationships and biology of Xenorhyncocoris are still very scarce. Furthermore, it is also interesting to investigate the potential distinct sexual dimorphism within the genus.

In the present study, the genus Xenorhyncocoris is revised, and all the known species are diagnosed and photographed. A new species from northeastern Borneo is described, of which we discover the macropterous male in addition to the micropterous female. DNA barcoding based on COI gene is used to associate the male with the female of the new species. The new discovery of male requires us to modify the diagnosis of Xenorhyncocoris, and also sheds light on our understanding of systematic relationships among Xenorhyncocoris and related genera. An updated female-based key to species of Xenorhyncocoris is also provided.

\section{Material and methods}

This study is based on specimens preserved in the Natural History Museum, London, United Kingdom (NHMUK), the Entomological Museum of China Agricultural University, Beijing, China (CAU), and the Zoologische Staatssammlung München, Munich, Germany (ZSM).

Male genitalia were soaked in hot $10 \% \mathrm{KOH}$ solution for approximately five minutes to remove soft tissue, rinsed in distilled water, and dissected under a Motic binocular dissecting microscope. Dissected genitalia were placed in a vial with glycerin and pinned under the corresponding specimen after examinations. Photographs were all taken using a Canon 7D Mark II digital camera with Canon micro lens EF $100 \mathrm{~mm}$ and MP-E $65 \mathrm{~mm}$ for habitus and an Olympus BX51 microscope for dissected body parts. Helicon Focus ver. 5.3 was used for image stacking. The distribution map was modified from a map downloaded from the online version of SimpleMapper (Shorthouse 2010). Measurements were obtained using a calibrated micrometer. Morphological terminology mainly follows Dougherty (1995) and Weirauch (2008a). The visible labial segments are numbered as II to IV because the first segment is lost or fused into the head capsule in most Reduviidae (Weirauch 2008b; Schuh et al. 2009). 
Two specimens (the holotype female and one paratype male) of Xenorhyncocoris attractivus sp. nov. collected from Mt Trus Madi, Sabah, Malaysia, were used for DNA extraction. Total genomic DNA was extracted from thoracic muscle tissues using DNeasy Blood and Tissue kit (Qiagen). DNA barcode sequences of 658-bp COI fragment were obtained by polymerase chain reaction (PCR) with primers LCO1490 (5'-GGTCAACAAATCATAAAGATATTGG-3' forward) and HCO2198 (5'-TAAACTTCAGGGTGACCAAAAAATCA-3' reverse) (Folmer et al. 1994). PCR and sequencing reactions were performed following protocols in Li et al. (2012). Sequences were submitted to GenBank with accession numbers MT452095 (male) and MT452097 (female). Sequence similarity was analyzed by Multiple Sequence Alignment by ClustalW in the software MEGA7 (Kumar et al. 2016).

\title{
Results
}

\author{
Class Insecta Linnaeus, 1758 \\ Order Hemiptera Linnaeus, 1758 \\ Suborder Heteroptera Latreille, 1810 \\ Family Reduviidae Latreille, 1807 \\ Subfamily Ectrichodiinae Amyot \& Audinet-Serville, 1843 \\ Tribe Ectrichodiini Amyot \& Audinet-Serville, 1843
}

Xenorhyncocoris Miller, 1938

Figs $1-59$

Xenorhyncocoris Miller, 1938: 135. Type species by original designation: Xenorhyncocoris caraboides Miller, 1938.

Xenorhyncocoris - Cook 1977: 64, 70. — Maldonado Capriles 1990: 78. — Putshkov \& Bérenger 1999: 92.

\section{Revised diagnosis}

This genus can be recognized within Ectrichodiinae by the following combination of characters: macropterous (male, based on $X$. attractivus sp. nov.) or micropterous (female); head club-shaped, subapically widened, distinctly longer than pronotum; ventral surface of anteocular part flat; antenniferous tubercle surrounded by lump-form process laterally; antennae four-segmented, with basiflagellomere shorter than other segments; labial segment II longest and dorsoventrally flattened, segment III inflated, segment IV flattened laterally; apex of prosternum acute, distinctly surpassing fore coxae; metathoracic gland evaporatorium invisible in lateral view; femora not thickened; apexes of tibiae bulbous; fossula spongiosa present on fore and mid tibiae; abdominal tergite II with three longitudinal ridges. In macropterous male, anterior pronotal lobe distinctly shorter but more than half as long as posterior lobe; scutellum broad, with $1+1$ widely separated apical prongs and $1+1$ lateral prongs; fore wing nearly reaching apex of abdomen. In micropterous female, anterior pronotal lobe distinctly longer than posterior lobe, swollen; scutellum broad, suberect or erect, with $1+1$ widely separated apical prongs; fore wing not reaching apex of scutellum.

\section{Redescription}

Macropterous male (based on X. attractivus sp. nov.)

Coloration. Body generally blackish brown (Figs 12-14); ocelli, basi- and disti- (except apical 1/3) flagellomeres, tarsi, anterolateral angles of each connexival segment and spiracles yellowish brown; connexivum faintly tinged with brown; apex of abdomen lighter. 
STRUCTURE. Body oblong; body surface generally glabrous, moderately shining and wrinkled. Body surface with decumbent, tiny pubescence, difficult to observe; antennae densely covered with decumbent and erect, short, white setae; inner surfaces of fore trochanter and femur with several sparsely distributed, erect, long, white setae; inner surfaces of tibiae (except basal 1/3) with decumbent and suberect, short setae; apexes of tibiae and ventral surfaces of tarsi densely covered with short golden setae (Figs 21-22).

HEAD (Figs 18-20). Elongate, club-shaped, widened at antenniferous tubercles, 1.35 times as long as pronotum; anteocular part distinctly longer than postocular part, ventral surface flat, midpoint slightly concave; eyes large, strongly protruding laterally, ventral margin far remote from ventral surface of head; width across eyes slightly broader than width between antenniferous tubercles; ocelli situated on tubercle; anteclypeus slightly elevated. Antennal insertion situated before middle of anteocular part but relatively far from apex of head; antenniferous tubercle produced, surrounded by lump-form process laterally (Fig. 19); antennae (Figs 12, 14) four-segmented, with antennal scape slightly shorter than head, pedicel longest and slightly curved, basiflagellomere shortest and distiflagellomere slightly longer than basiflagellomere. Labium (Figs 19-20) robust; labial segment II longest and dorsoventrally flattened, apex reaching posterior margin of eye, strongly curved at base; segment III strongly inflated; segment IV strongly flattened laterally, knife-like.

Pronotum (Figs 18-19). Trapezoidal, wider than long; anterior pronotal lobe distinctly shorter but more than half as long as posterior lobe, slightly swollen, with medial longitudinal sulcus restricted in extreme base; posterior lobe broad, with deep, carinulate, medial longitudinal sulcus and a pair of deep, carinulate, lateral sulci; transverse sulcus distinct; lateral pronotal margins constricted; posterior margin slightly convex. Prosternum (Fig. 20) strongly developed, distinctly surpassing fore coxae, apically acute. Scutellum (Fig. 18) broad, with 1+1 widely separated apical prongs and 1+1 lateral prongs; midpoint of scutellum depressed. Anterior margin of mesopleuron with a row of distinct punctuations (Fig. 19). Mesosternum (Fig. 20) with a shallow, medial, longitudinal furrow. Metapleuron (Fig. 19) longer than high. Metasternum (Fig. 20) slightly swollen on both sides. Metathoracic gland callus present in lateral view; metathoracic gland evaporatorium small, not extend dorsally in lateral view.

Legs. Slender (Figs 12-14). Femora not thickened, slightly sinuated subapically; tibiae slenderer than respective femora, straight; apex of fore tibia bulbous, laterally compressed forming a blunt, weak dorsal carina (Fig. 21); tarsomere III subequal to combined length of tarsomeres I and II; fore and mid tibiae with fossula spongiosa occupying about apical 0.15 of their ventral surface (Fig. 22).

WiNGS. Well developed. Fore wing (Fig. 23) nearly reaching apex of abdomen; corium with majority parts of $\mathrm{M}$ and $\mathrm{Cu}$ separate; membrane with base of outer cell distinctly shorter than inner cell, distal part of R forming a close cell with $\mathrm{M}$, distal part of $\mathrm{M}$ extending beyond apex of outer cell. Hind wing (Fig. 24) with distal parts of Sc, R and M reaching outer margin; hamus nearly reaching base of hind wing; only one secondary vein.

AbDomen. Ovoid, with lateral outline rounded (Figs 12, 14). Abdominal tergite II with three longitudinal ridges. Ventral laterotergites II to VI distinctly separate from respective sternites. Intersternal sutures of segments II to VI carinulate; midpoint of anterior margins of sternites IV to VI curved anteriorly; anterior margin of sternite VII strongly curved anteriorly; segment VII distinctly expanded posteriorly (Fig. 25); segment VIII invisible at resting state (Fig. 25). Spiracles round.

Male Genitalia. Pygophore (Figs 26-28) short, oblong; median process directed dorsoposteriad. Parameres (Figs 29-32) relatively stout, bent, with a subapical process. 


\section{Micropterous female}

Coloration. Body generally brown to blackish brown (Figs 1-3, 15-17, 46-48, 57-59); tarsi, anterolateral and posterolateral angles of each connexival segment, apical margin of abdomen, spiracles and valvula I yellowish brown.

STRUCTURE. Body shape and vestiture similar to those in male, but differs in the following characteristics: body robust; antennal scape and basal half of pedicel bare; lateral margins of prosternum with suberect, short, golden setae; head thickened, 1.8-2.2 times as long as pronotum; eyes small; width between antenniferous tubercles broader than width across eyes; ocelli strongly reduced; anteclypeus not elevated; antennal scape distinctly shorter than head; pronotum nearly square; anterior pronotal lobe much longer than and as wide as or slightly narrower than posterior lobe, swollen dorsally; medial longitudinal sulcus of pronotum reduced to deep, medial depression; lateral margins of anterior pronotal lobe marginated; posterior margin of pronotum concave; prosternum much longer, reaching or surpassing anterior margins of mid coxae; scutellum suberect or erect, with prongs weakly developed; fossula spongiosa larger, occupying about apical 0.2 of ventral surface of fore and mid tibiae; fore wing not reaching apex of scutellum; abdomen broader, with ventral surface slightly flattened in middle.

Female Genitalia. Platelike (Figs 10-11, 42-43, 55-56, 59); tergite VIII transverse, anterior and posterior margins nearly straight; tergite IX large, trapezoidal, with transverse depression subapically; posteromedian margin of valvifer I slightly sinuate; valvula I small, triangular, with posterior margin slightly concave; styloid visible in resting state.

\section{Diversity and distribution}

Four species, occurring in the Oriental Region (Fig. 60).

\section{Female-based key to species of Xenorhyncocoris Miller, 1938}

1. Body length about $37 \mathrm{~mm}$; head 2.2 times as long as pronotum; anteocular part 1.3 times as long as postocular part; labial segment II surpassing posterior margin of eye, curved dorsally, approaching ventral surface of head; apex of prosternum almost reaching posterior margins of mid coxal cavities

X. caraboides Miller, 1938

- Body length about $34 \mathrm{~mm}$ or less; head 1.8-1.9 times as long as pronotum; anteocular part 1.4-1.7 times as long as postocular part; labial segment II reaching posterior margin of eye, straight or curved dorsally; apex of prosternum reaching middle of mid coxae or less

2. Body blackish brown; labial segment II curved dorsally, approaching ventral surface of head; pronotum 1.15 times as broad as its length along midline; scutellum erect; fore wing reaching middle of scutellum $X$. attractivus sp. nov.

- Body brown; labial segment II straight; pronotum as broad as its length along midline; scutellum suberect; fore wing surpassing middle of scutellum

3. Anteocular part 1.4 times as long as postocular part; labial segment II 1.9 times as long as segment III, with ventral surface thickened at apical $2 / 3$; prosternum reaching anterior margins of mid coxae

X. princeps Miller, 1949

- Anteocular part 1.7 times as long as postocular part; labial segment II 1.6 times as long as segment III, with apex bulbous; prosternum reaching middle of mid coxae 
Xenorhyncocoris caraboides Miller, 1938

Figs 1-11

Xenorhyncocoris caraboides Miller, 1938: 135. Holotype (†): Indonesia, Bengkulu, NHMUK.

Xenorhyncocoris caraboides - Cook 1977: 70. - Maldonado Capriles 1990: 78. — Putshkov \& Bérenger 1999: 92.

\section{Diagnosis}

Only micropterous female known. Body length about $37 \mathrm{~mm}$; brown; head 2.2 times as long as pronotum; anteocular part 1.3 times as long as postocular part; labial segment II 1.9 times as long as segment III, surpassing posterior margin of eye, strongly curved dorsally, closing to ventral surface of head; pronotum 1.1 times as broad as its length, anterior lobe moderately swollen, posterior lobe 1.1 times as broad as anterior lobe; prosternum almost reaching posterior margins of mid coxal cavities; scutellum suberect; fore wing reaching apical $2 / 3$ of scutellum.

\section{Material examined}

\section{Holotype}

INDONESIA • $\circ$; Bengkulu, Lebong Tandai; $3.04107^{\circ}$ S, $101.98170^{\circ}$ E; 1920-1923; C.J. Brooks leg.; NHMUK 013587632.

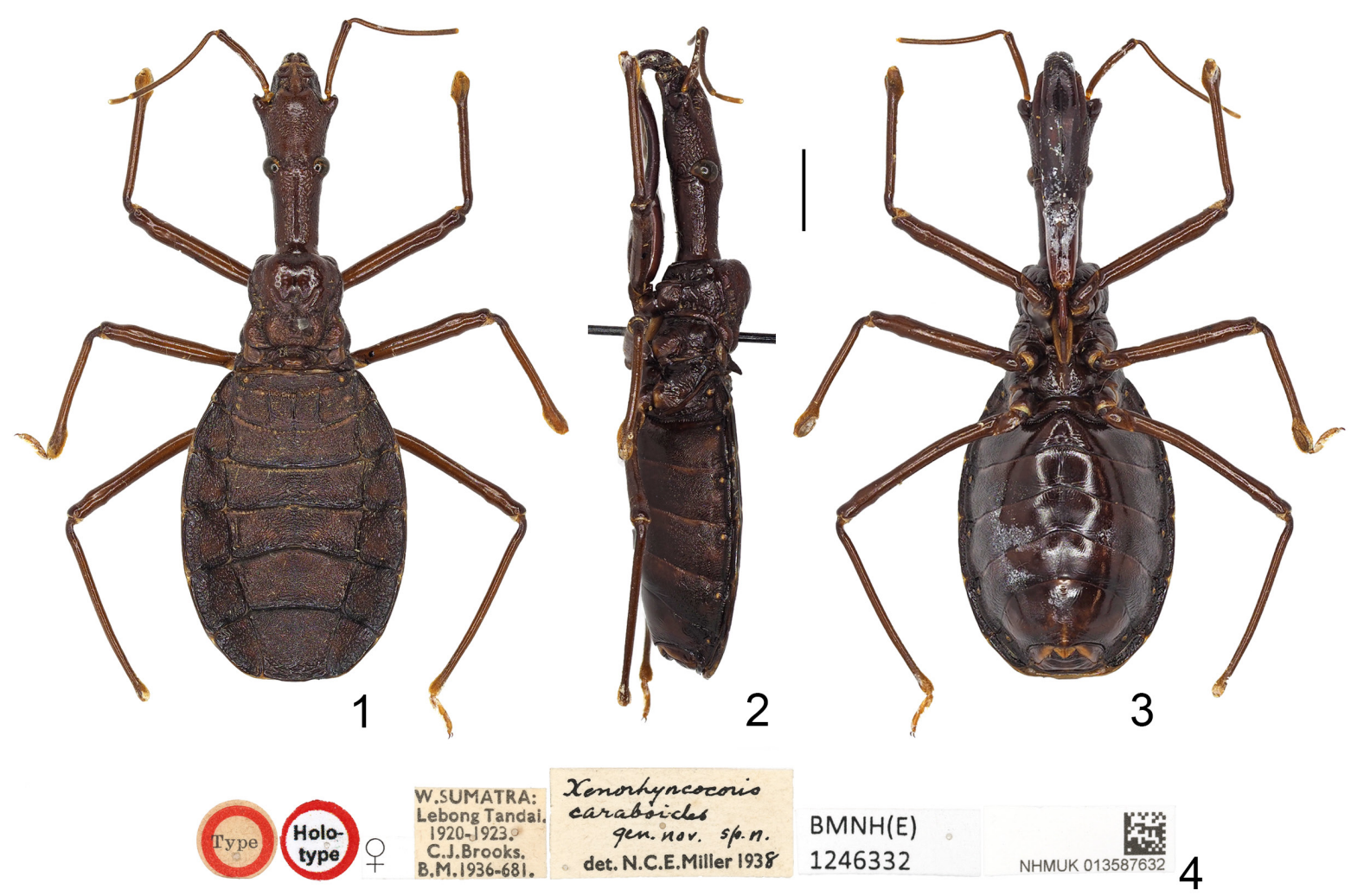

Figs 1-4. Xenorhyncocoris caraboides Miller, 1938, holotype, $q$ (NHMUK 013587632), habitus. 1. Dorsal view. 2. Lateral view. 3. Ventral view. 4. Labels. Scale bar: $1-3=5.00 \mathrm{~mm}$. 


\section{Redescription}

\section{Micropterous female}

Measurements [in mm, $\mathrm{n}=1$ (holotype)] (Figs 1-3). Length of body (to apex of abdomen) $=36.70$; length of head $=11.80$; length of anteocular part $=5.40$; length of postocular part $=4.20$; maximum width of head $=5.00$; width across eyes $=3.90$; interocular space $=2.00$; length of antennal segments I-IV $=$ $4.70,6.50,1.90$, ? (missing); length of labial segments II-IV $=9.00,4.75,3.00$; length of pronotum $=$ 5.40 ; length of anterior pronotal lobe $=3.60$; length of posterior pronotal lobe $=1.80$; width of anterior pronotal lobe $=5.50$; width of posterior pronotal lobe $=5.90$; median length of scutellum $=1.30$; basal
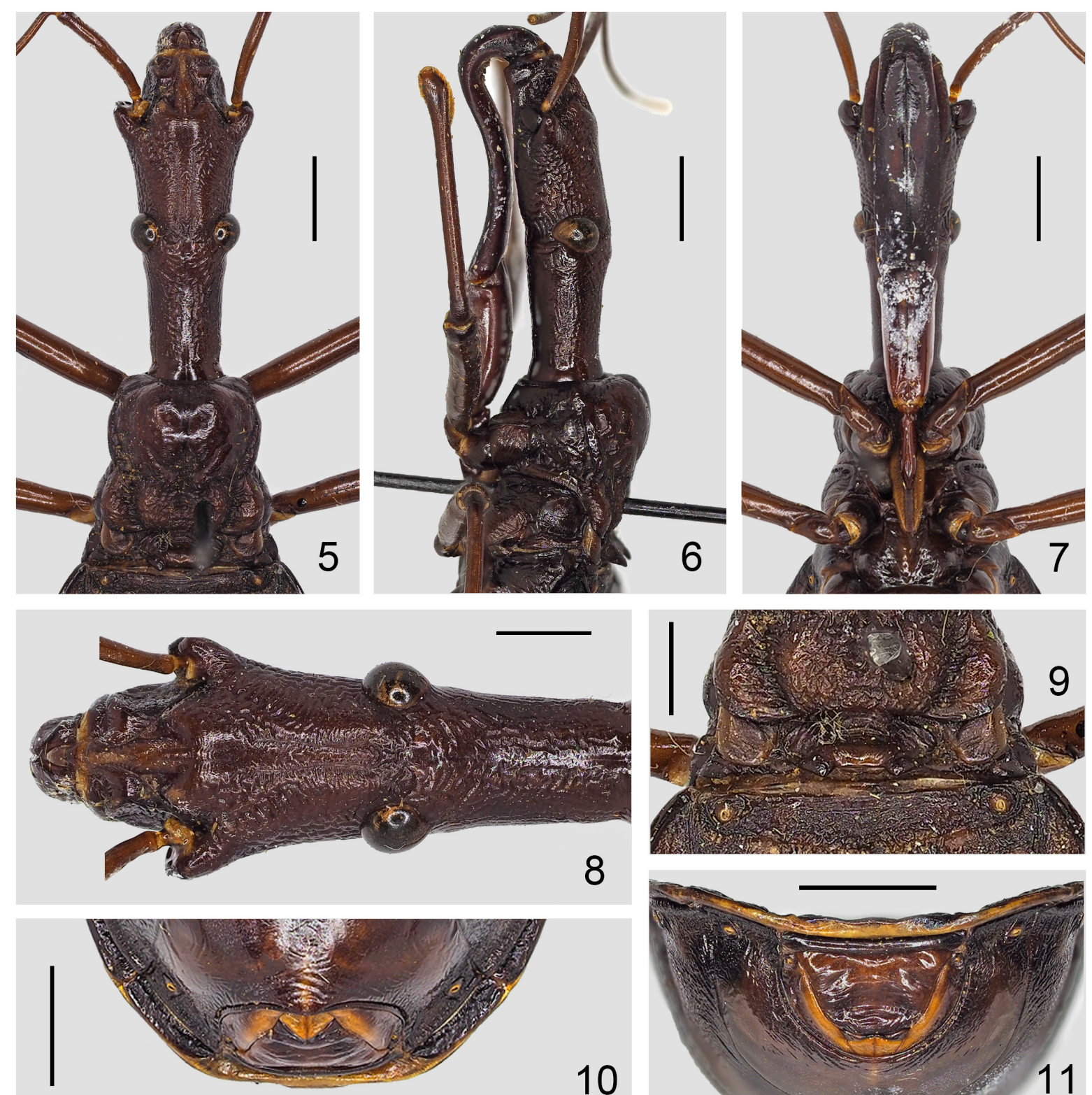

10


Figs 5-11. Xenorhyncocoris caraboides Miller, 1938, holotype, $q$ (NHMUK 013587632). 5. Anterior part of body, dorsal view. 6. Same, lateral view. 7. Same, ventral view. 8. Head, dorsal view. 9. Scutellum, dorsal view. 10. Posterior part of abdomen, ventral view. 11. Same, caudal view. Scale bars: $5-7,10-$ $11=3.00 \mathrm{~mm} ; 8-9=2.00 \mathrm{~mm}$. 
width of scutellum $=3.10$; apical prongs space $=1.50$; length of fore femur, tibia, tarsus $=9.40,8.70$, ? (missing); length of mid femur, tibia, tarsus $=8.70,8.20,2.30$; length of hind femur, tibia, tarsus $=11.50$, $11.50,2.40$; length of fore wing $=1.40$; length of abdomen $=17.80$; maximum width of abdomen $=$ 12.90 .

Coloration. Body generally brown; apical half of valvifer I light brown. Other body parts as in generic description.

Structure. Body shape and vestiture as in generic description. Head (Figs 5-8) 2.2 times as long as pronotum, 2.35 times as long as its maximum width; anteocular part 1.3 times as long as postocular part; antennal scape 0.9 times as long as anteocular part; labial segment II 1.9 times as long as segment III, distinctly surpassing posterior margin of eye, with apical $3 / 4$ strongly curved dorsally, approaching ventral surface of head (Fig. 6); labial segment III strongly inflated (Figs 6-7). Pronotum (Figs 5-6) 1.1 times as broad across humeral angles as its length; anterior lobe two times as long as posterior lobe, moderately swollen dorsally; posterior lobe 1.1 times as broad as width of anterior lobe; prosternum (Fig. 7) almost reaching posterior margins of mid coxal cavities; scutellum (Fig. 9) broad, suberect, with apical prongs short. Fore wing (Fig. 9) scale-like, reaching apical $2 / 3$ of scutellum. Abdomen ovoid, 1.4 times as long as its maximum width.

Female Genitalia (Figs 10-11). As in generic description.

\section{Male}

Unknown.

\section{Distribution}

Indonesia (Bengkulu: Lebong Tandai).

Xenorhyncocoris attractivus $\mathrm{sp}$. nov. urn:1sid:zoobank.org:act:6AA758C6-87A6-40B8-A84E-3BFE76CCABB6

Figs $12-45$

\section{Diagnosis}

Macropterous male: as in generic diagnosis. Micropterous female: body length about $33.4 \mathrm{~mm}$; blackish brown; head 1.8 times as long as pronotum; anteocular part 1.45 times as long as postocular part; labial segment II 1.65 times as long as segment III, reaching posterior margin of eye, strongly curved dorsally, closing to ventral surface of head; pronotum 1.15 times as broad as its length, anterior lobe moderately swollen, posterior lobe 1.15 times as broad as anterior lobe; prosternum reaching middle of mid coxae; scutellum erect; fore wing reaching middle of scutellum.

\section{Etymology}

The specific epithet 'attractivus' (meaning 'interesting') refers to our first impressions of this new species.

\section{Material examined}

\section{Holotype}

MALAYSIA • ${ }^{+}$; Sabah, Mt Trus Madi; $5.44881^{\circ}$ N, $116.45239^{\circ}$ E; 1180 m a.s.1.; May 2017; W. Zhang leg.; CAU-RE-0000004. 


\section{Paratypes}

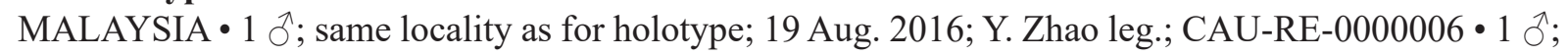
same locality as for holotype; 10 Feb. 2017; Y. Liu leg.; CAU-RE-0000007 • 1 §’; Sabah, Tawau Hills

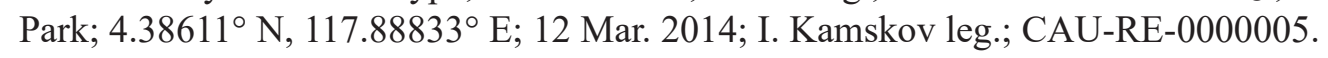
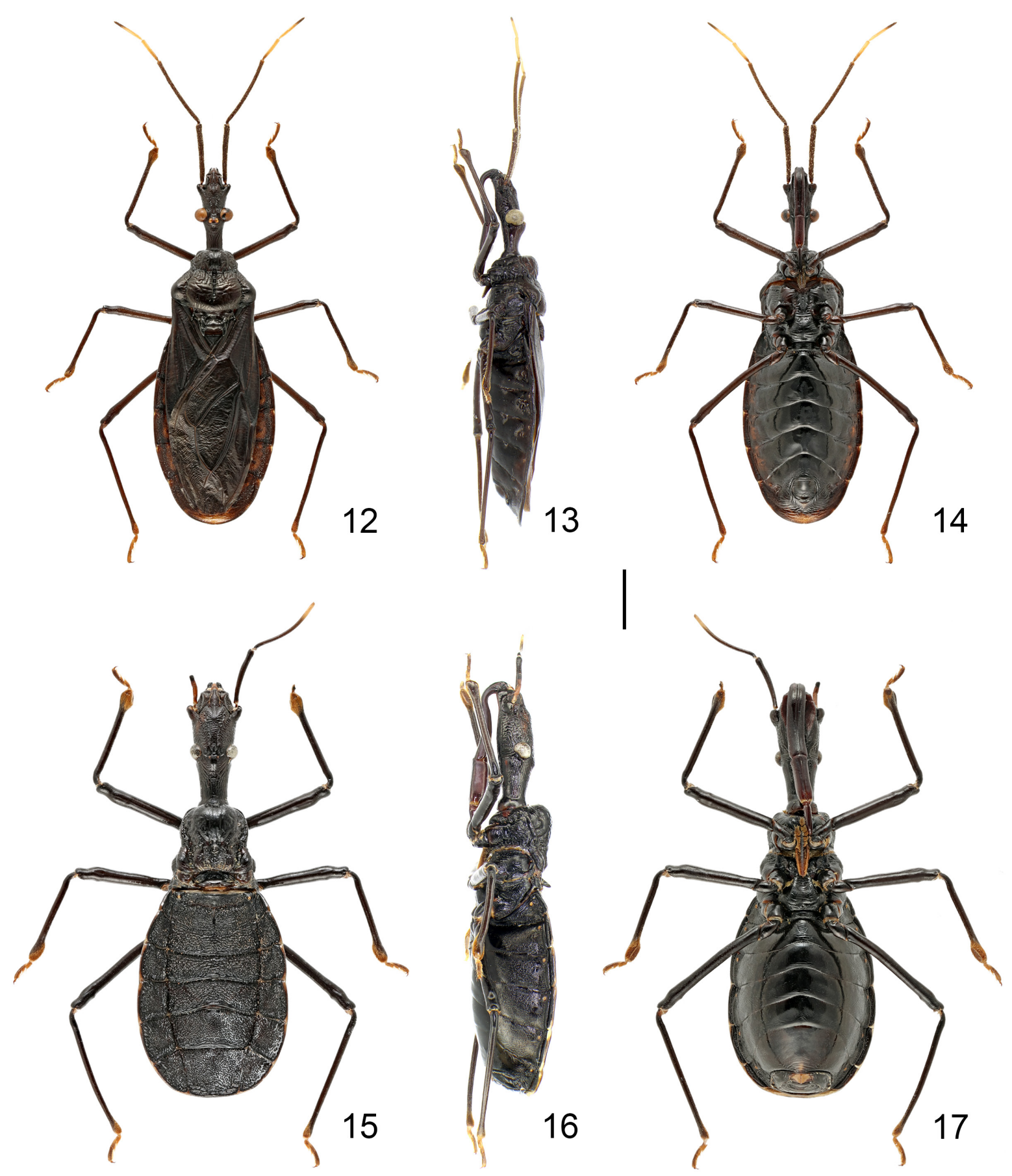

Figs 12-17. Xenorhyncocoris attractivus sp. nov., habitus. 12. Paratype, $\widehat{\partial}$ (CAU-RE-0000005), dorsal view. 13. Same, lateral view. 14. Same, ventral view. 15. Holotype, o (CAU-RE-0000004), dorsal view. 16. Same, lateral view. 17. Same, ventral view. Scale bar $=5.00 \mathrm{~mm}$. 


\section{Description}

\section{Macropterous male}

MEASuREMENTS [in mm, $\mathrm{n}=3$ (paratypes)] (Figs 12-14). Length of body (to apex of abdomen) = 26.60-28.70; length of head $=6.50-6.70$; length of anteocular part $=3.20-3.30$; length of postocular part $=2.10-2.20$; width across eyes $=3.10-3.15$; interocular space $=1.00$; interocellar space $=0.20$ 0.25 ; length of antennal segments I-IV $=4.30-4.60,5.50-5.90,1.80-2.00,2.40-2.60$; length of labial segments II-IV $=3.80-4.10,2.50-2.60,1.80-2.00$; length of pronotum $=4.80-5.00$; length of anterior pronotal lobe $=1.70-1.80$; length of posterior pronotal lobe $=3.10-3.20$; width of anterior pronotal lobe $=3.70-3.80$; width of posterior pronotal lobe $=6.70-6.90$; median length of scutellum $=1.40$; basal width of scutellum $=3.10-3.40$; apical prongs space $=1.20-1.40$; length of fore femur, tibia, tarsus $=$ $5.80-6.00,6.50-6.70,1.70-2.00$; length of mid femur, tibia, tarsus $=5.50-5.80,5.90-6.30,1.70-1.90$; length of hind femur, tibia, tarsus $=7.70-8.60,8.50-9.30,2.00-2.30$; length of fore wing $=17.10-18.00$; length of abdomen $=14.50-15.75$; maximum width of abdomen $=8.80-9.70$.

Coloration. As in generic description.

STRUCTURE. Body shape and vestiture as in generic description. Head (Figs 18-20) with anteocular part 1.5 times as long as postocular part; interocular space slightly narrower than diameter of single eye; antennal scape 1.4 times as long as anteocular part; labial segment II 1.55 times as long as segment III, with apical $2 / 3$ curved dorsally, approaching ventral surface of head (Fig. 19). Pronotum (Figs 18-19) 1.4 times as broad across humeral angles as its length; posterior lobe 1.8 times as long as, and 1.8 times as broad as anterior lobe; prosternum (Fig. 20) reaching middle of mesosternum; scutellum (Fig. 18) with apical prongs well developed and widely separated basally, lateral prongs papilla-shaped. Abdomen 1.65 times as long as its maximum width.

Male Genitalia. Pygophore (Figs 26-28) rounded posteriorly, with posterior margin edge-liked; median process broad, lamelliform, apex rounded; paramere insertion with a protuberance (Fig. 26). Parameres (Figs 29-32) bent and slightly twisted at midpoint, with an obtuse subapical process. Phallus (33-36) with articulatory apparatus thick; basal plates arched, basal plate bridge relatively thin; basal plate extension short and thick; dorsal sclerotized plate posteriorly narrowed, apically rounded, with $1+1$ paralleled rows of tiny denticles at apical half (Fig. 33); lateral process of dorsal sclerotized plate flake-like, apex with about seven tiny denticles (Fig. 36); struts converged anteriorly, parallele in most of their length and fused at midpoint; endosoma with a broad, flattened, laterally reflexed sclerite (Figs 33, 35-36); ventral surface of phallus with 1+1 blade-like, apically sharped sclerites (Figs 34-35).

\section{Micropterous female}

MeAsurements [in mm, $\mathrm{n}=1$ (holotype)] (Figs 15-17). Length of body (to apex of abdomen) $=33.40$; length of head $=9.80$; length of anteocular part $=4.60$; length of postocular part $=3.20$; maximum width of head $=4.55$; width across eyes $=3.90$; interocular space $=1.90$; length of antennal segments $\mathrm{I}-\mathrm{IV}=4.50,6.00$, ? (missing), ? (missing); length of labial segments II-IV $=6.60,4.00,2.50$; length of pronotum $=5.40$; length of anterior pronotal lobe $=3.70$; length of posterior pronotal lobe $=1.80$; width of anterior pronotal lobe $=5.50$; width of posterior pronotal lobe $=6.20$; median length of scutellum $=$ 1.30 ; basal width of scutellum $=3.30$; apical prongs space $=1.40$; length of fore femur, tibia, tarsus $=$ $7.80,8.40,2.10$; length of mid femur, tibia, tarsus $=7.80,8.00,2.20$; length of hind femur, tibia, tarsus $=10.00,10.90,2.30$; length of fore wing $=1.20$; length of abdomen $=16.40$; maximum width of abdomen $=12.10$.

COLORATION. Body generally blackish brown; apical $1 \frac{1}{3}$ of antennal pedicel, middle spot near posterior margin of abdominal sternite VII and valvula I yellowish brown. Other body parts as in generic description. 

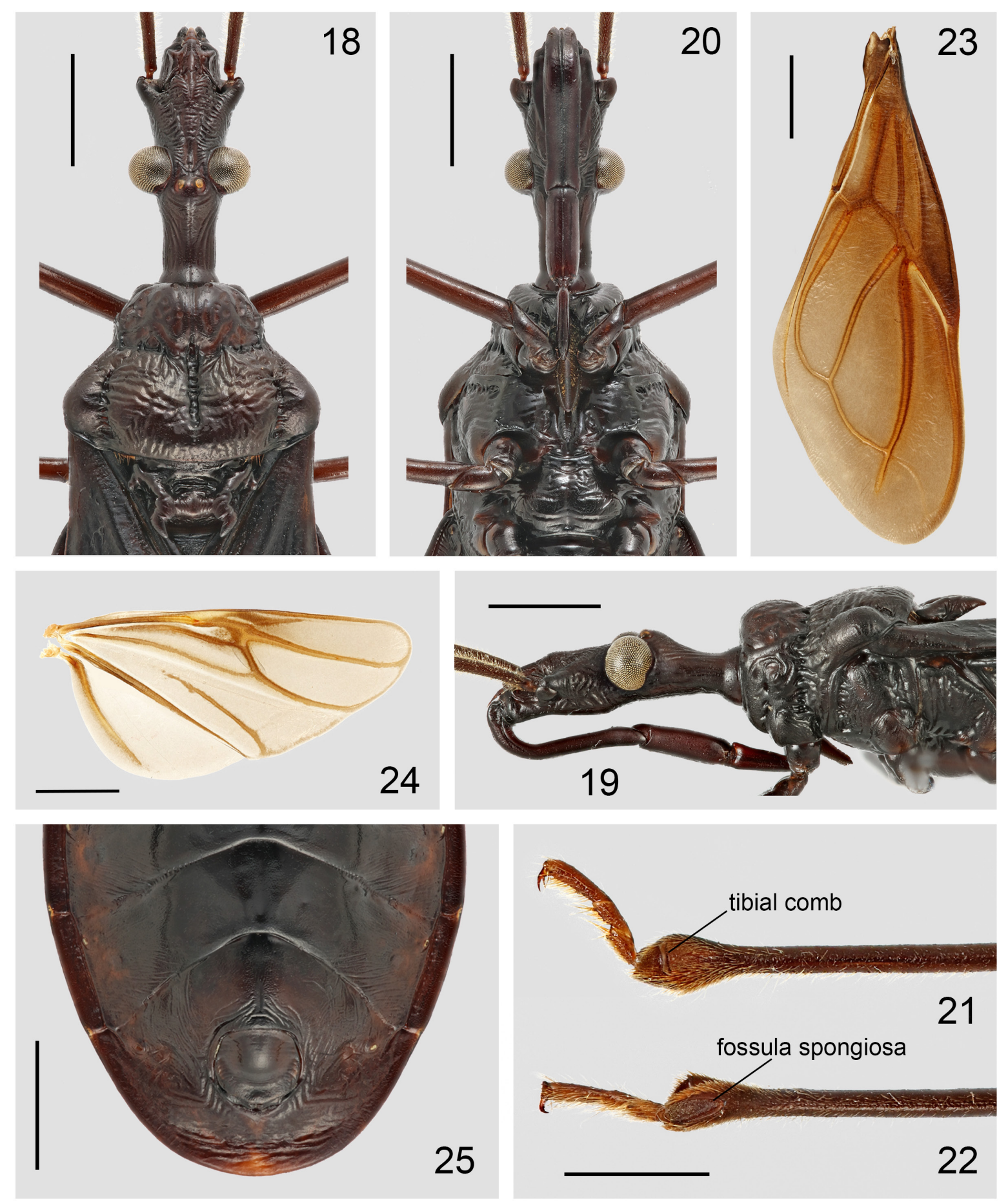

Figs 18-25. Xenorhyncocoris attractivus sp. nov., paratype, $\widehat{\jmath}$ (CAU-RE-0000006). 18. Anterior part of body, dorsal view. 19. Same, lateral view. 20. Same, ventral view. 21. Anterior part of right fore leg, dorsal view. 22. Same, lateral view. 23. Right fore wing, dorsal view. 24. Right hind wing, dorsal view. 25. Posterior part of abdomen, ventral view. Scale bars: $18-20,23-25=3.00 \mathrm{~mm} ; 21-22=2.00 \mathrm{~mm}$. 



28


33

Figs 26-36. Xenorhyncocoris attractivus sp. nov., paratype, $\widehat{\jmath}$ (CAU-RE-0000006). 26. Pygophore, dorsal view. 27. Same, lateral view. 28. Same, caudal view. 29-32. Paramere. 33. Phallus, dorsal view. 34. Same, lateral view. 35. Same, ventral view. 36. Same, front view. Scale bar: $26-32=1.00 \mathrm{~mm}$; $33-36=0.75 \mathrm{~mm}$. 
STRUCTURE. Body shape and vestiture as in generic description. Head (Figs 37-40) 1.8 times as long as pronotum, 2.15 times as long as its maximum width; anteocular part 1.45 times as long as postocular part; antennal scape as long as anteocular part; labial segment II 1.65 times as long as segment III, reaching posterior margin of eye, with apical $3 / 4$ distinctly curved dorsally, approaching ventral surface of head (Fig. 38); labial segment III moderately inflated (Figs 38-39). Pronotum (Figs 37-38) 1.15 times as broad across humeral angles as its length; anterior lobe two times as long as posterior lobe; posterior lobe 1.15 times as broad as width of anterior lobe; prosternum (Fig. 39) reaching middle of mid coxae; scutellum (Fig. 41) broad, erect, with apical prongs short. Fore wing (Fig. 41) scale-like, short, reaching middle of scutellum. Abdomen ovoid, 1.35 times as long as its maximum width.
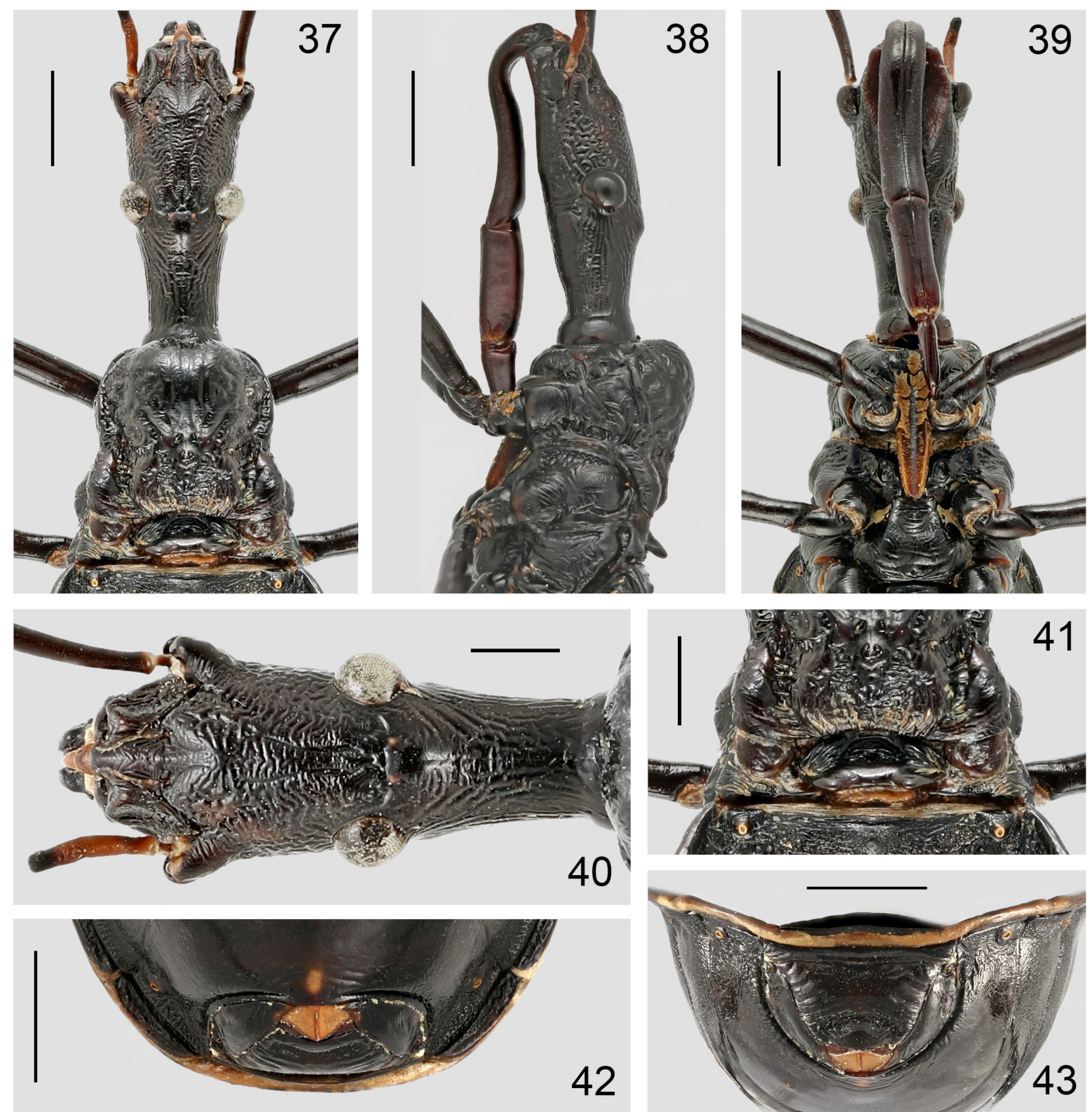

Figs 37-43. Xenorhyncocoris attractivus sp. nov., holotype, $\subsetneq$ (CAU-RE-0000004). 37. Anterior part of body, dorsal view. 38. Same, lateral view. 39. Same, ventral view. 40. Head, dorsal view. 41. Scutellum, dorsal view. 42. Posterior part of abdomen, ventral view. 43. Same, caudal view. Scale bars: 37-39, $42-43=3.00 \mathrm{~mm} ; 40-41=2.00 \mathrm{~mm}$. 
Female genitalia (Figs 42-43). As in generic description.

\section{Distribution}

Malaysia (Sabah: Mt Trus Madi).
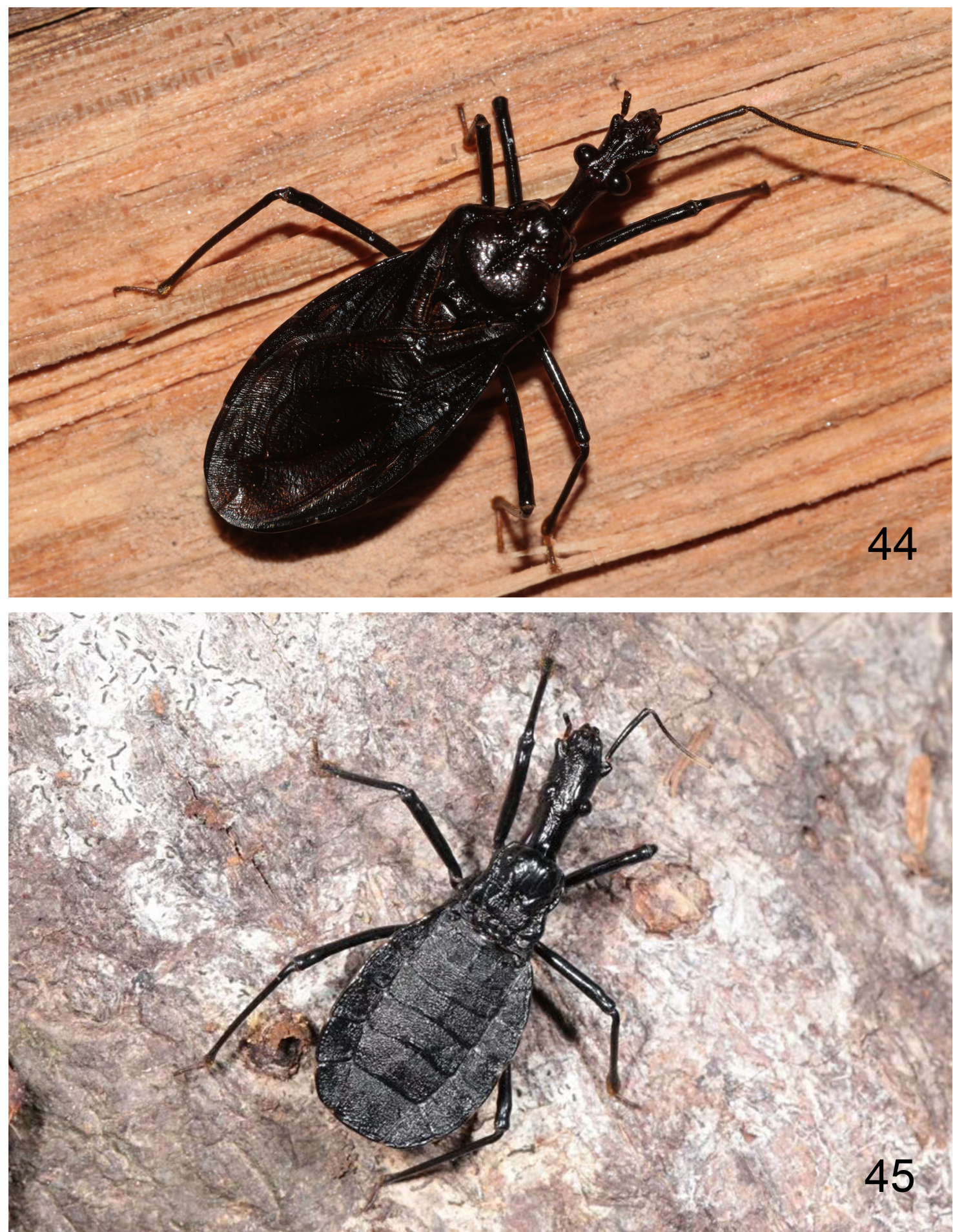

Figs 44-45. Xenorhyncocoris attractivus sp. nov. 44. Living male. 45. Living female. (C) Weiwei Zhang. 


\section{Comparative notes}

Because the males of other species of Xenorhyncocoris are unknown, the following comparisons are based on females. Xenorhyncocoris attractivus sp. nov. resembles $X$. caraboides in the dorsally curved labial segment II, but it can be easily distinguished from the latter by: the much smaller size (body length $33.4 \mathrm{~mm}$ in $X$. attractivus sp. nov. vs about $37 \mathrm{~mm}$ in $X$. caraboides); head 1.8 times as long as pronotum (vs 2.2 times as long as pronotum in X. caraboides); anteocular part 1.45 times as long as postocular part (vs 1.3 times as long as postocular in $X$. caraboides); labial segment II reaching posterior margin of eye, 1.65 times as long as segment III (vs distinctly surpassing posterior margin of eye, 1.9 times as long as segment III in $X$. caraboides); apex of prosternum reaching middle of mid coxae (vs almost reaching posterior margins of mid coxal cavities in X. caraboides).

Xenorhyncocoris attractivus sp. nov. can be separated from X. schoenitzeri by: anteocular part 1.45 times as long as postocular part (vs 1.7 times in X. schoenitzeri); labial segment II dorsally curved, segment III moderately inflated (vs labial segment II straight, apically bulbous, segment III strongly inflated in $X$. schoenitzeri); pronotum 1.15 times as broad as its length (vs width of pronotum equal to its length in $X$. schoenitzeri); posterior pronotal lobe 1.15 times as broad as width of anterior lobe (vs posterior lobe as broad as anterior lobe in $X$. schoenitzeri).

Xenorhyncocoris attractivus sp. nov. is most similar to X. princeps in the shape of the head and the moderately inflated labial segment III. The new species differs from the latter by the following characters: labial segment II dorsally curved, 1.65 times as long as segment III (vs labial segment II straight, apical $2 / 3$ of ventral surface slightly thickened, 1.9 times as long as segment III in X. princeps); pronotum 1.15 times as broad as its length (vs width of pronotum equal to its length in $X$. princeps); posterior pronotal lobe 1.15 times as broad as width of anterior lobe (vs posterior lobe as broad as anterior lobe in $X$. princeps); apex of prosternum reaching middle of mid coxae (vs reaching anterior margins of mid coxal cavities in $X$. princeps).

Moreover, several additional characters can also distinguish $X$. attractivus sp. nov. from its congeners: the blackish brown body color (vs brown in other species); the $\sim 90^{\circ}$ erected scutellum (vs $\sim 45^{\circ}$ suberected scutellum in other species); apex of fore wing reaching middle of scutellum (vs surpassing middle but not reaching apex of scutellum in other species). Species of the genus Xenorhyncocoris can be distinguished with the key above.

Xenorhyncocoris princeps Miller, 1949

Figs 46-56

Xenorhyncocoris princeps Miller, 1949: 235. Holotype (q): Malaysia, Selangor, NHMUK.

Xenorhyncocoris princeps - Cook 1977: 70. — Maldonado Capriles 1990: 78. — Putshkov \& Bérenger 1999: 92.

\section{Diagnosis}

Only micropterous female known. Body length about $32 \mathrm{~mm}$; brown; head 1.8 times as long as pronotum; anteocular part 1.4 times as long as postocular part; labial segment II 1.9 times as long as segment III, reaching posterior margin of eye, nearly straight, apical $2 / 3$ of ventral surface slightly thickened; pronotum as broad as its length, anterior lobe strongly swollen, posterior lobe as broad as width of anterior lobe; prosternum reaching anterior margins of mid coxal cavities; scutellum suberect; fore wing reaching apical $3 / 4$ of scutellum. 


\section{Material examined}

\section{Holotype}

MALAYSIA • + ; Selangor, Ulu Tinggi; 3.49240 N, $101.51658^{\circ}$ E; Feb. 1941; Goolden leg.; NHMUK 013587631.

\section{Redescription}

\section{Micropterous female}

Measurements [in mm, $\mathrm{n}=1$ (holotype)] (Figs 46-48). Length of body (to apex of abdomen) $=31.80$; length of head $=9.50$; length of anteocular part $=4.10$; length of postocular part $=2.90$; greatest width of head $=4.60$; width across eyes $=3.80$; interocular space $=1.70$; length of antennal segments I-IV $=4.10$, $4.80,1.50,2.20$; length of labial segments II-IV $=6.15,3.20,2.40$; length of pronotum $=5.30$; length of anterior pronotal lobe $=3.50$; length of posterior pronotal lobe $=1.80$; width of anterior pronotal lobe $=5.50$; width of posterior pronotal lobe $=5.60$; median length of scutellum $=1.50$; basal width of scutellum $=3.00$; apical prongs space $=1.35$; length of fore femur, tibia, tarsus $=7.50,7.00,1.70$; length
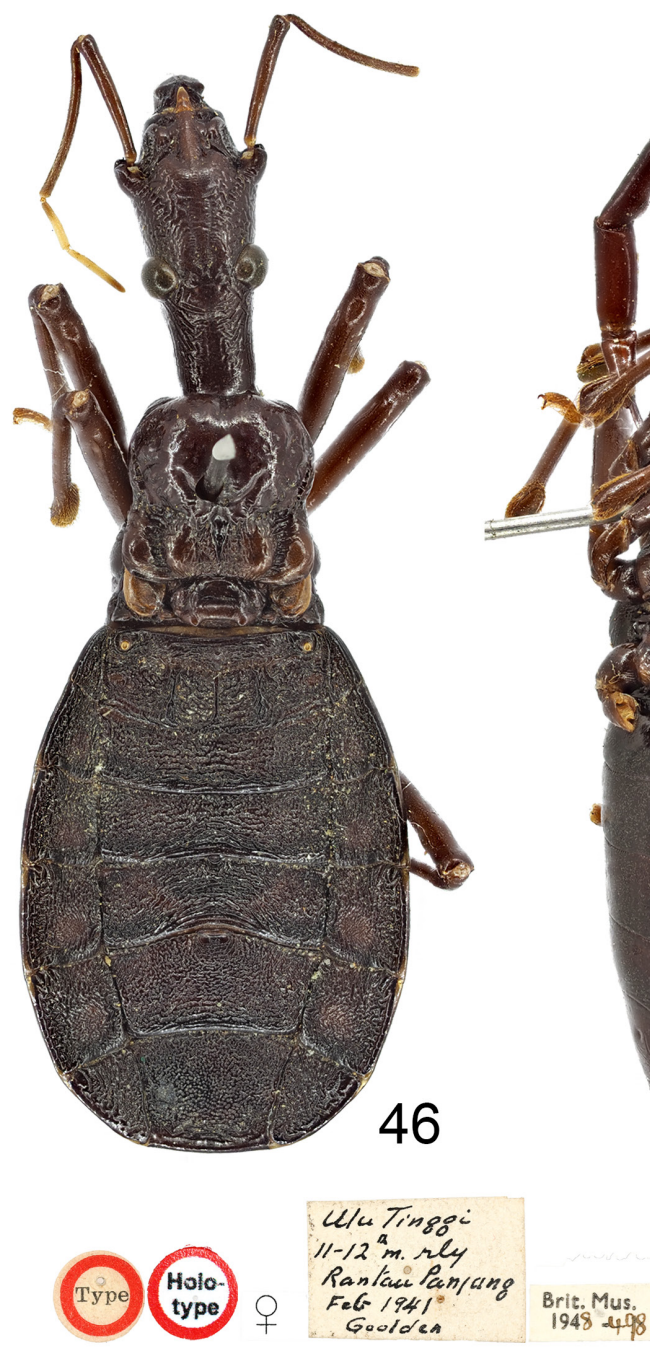

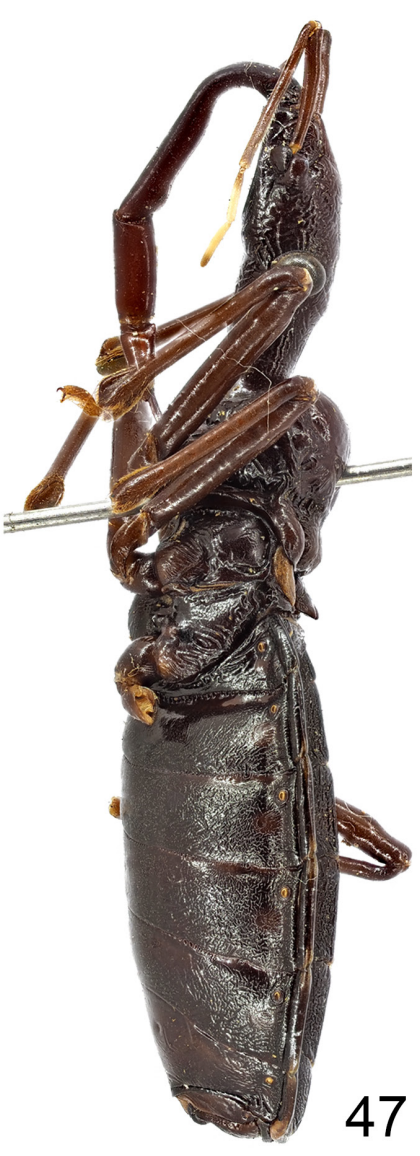

47



Kenorhyncecoris
princepos s/an.
det. N.C.E. Miller.194\% 1246333

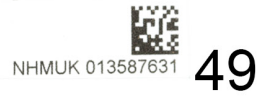

Figs 46-49. Xenorhyncocoris princeps Miller, 1949, holotype, ㅇ (NHMUK 013587631), habitus. 46. Dorsal view. 47. Same, lateral view. 48. Same, ventral view. 49. Labels. Scale bar: $46-48=5.00 \mathrm{~mm}$. 
of mid femur, tibia, tarsus $=7.20,6.60$, ? (missing); length of hind femur, tibia, tarsus $=9.80,9.70$, ? (missing); length of fore wing $=1.50$; length of abdomen $=15.40$; maximum width of abdomen $=11.40$.

COLORATION. Body generally brown; basi- and disti- (except apical 1/3) flagellomeres and posteromedian margin of valvifer I yellowish brown. Other body parts as in generic description.

STRUCTURE. Body shape and vestiture as in generic description. Head (Figs 50-53) 1.8 times as long as pronotum, 2.1 times as long as its maximum width; anteocular part 1.4 times as long as postocular part;
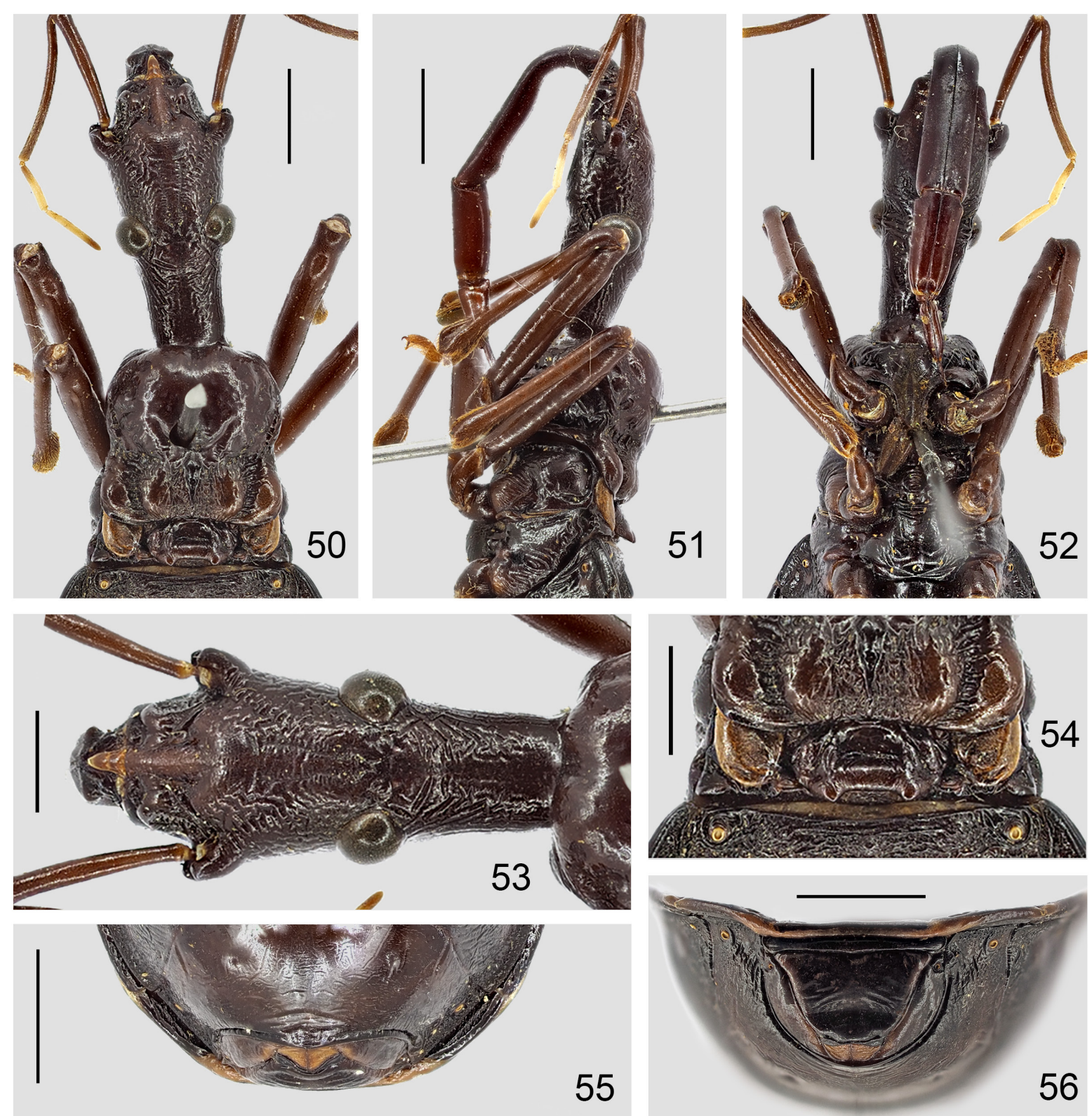

Figs 50-56. Xenorhyncocoris princeps Miller, 1949, holotype, $q$ (NHMUK 013587631). 50. Anterior part of body, dorsal view. 51. Same, lateral view. 52. Same, ventral view. 53. Head, dorsal view. 54. Scutellum, dorsal view. 55. Posterior part of abdomen, ventral view. 56. Same, caudal view. Scale bars: $50-52,55-56=3.00 \mathrm{~mm} ; 53-54=2.00 \mathrm{~mm}$. 
antennal scape as long as anteocular part; labial segment II 1.9 times as long as segment III, reaching posterior margin of eye, nearly straight, ventral surface far remote from ventral surface of head, apical $2 / 3$ of ventral surface slightly thickened (Fig. 51); labial segment III moderately inflated (Figs 51-52). Pronotum (Figs 50-51) as broad across humeral angles as its length; anterior lobe 1.95 times as long as posterior lobe; posterior lobe as broad as width of anterior lobe; prosternum (Fig. 52) reaching anterior margins of mid coxal cavities; scutellum (Fig. 54) broad, suberect, with apical prongs short. Fore wing (Fig. 54) scale-like, reaching apical $3 / 4$ of scutellum. Abdomen ovoid, 1.35 times as long as its maximum width.

Female Genitalia (Figs 55-56). As in generic description.

Male

Unknown.

\section{Distribution}

Malaysia (Selangor: Ulu Tinggi).

Xenorhyncocoris schoenitzeri Putshkov \& Bérenger, 1999

Figs 57-59

Xenorhyncocoris schoenitzeri Putshkov \& Bérenger, 1999: 89, 92. Holotype (\$): Indonesia, West Sumatra, ZSM.

\section{Diagnosis}

Only micropterous female known. Body length about $34 \mathrm{~mm}$; brown; head 1.9 times as long as pronotum; anteocular part 1.7 times as long as postocular part; labial segment II 1.6 times as long as segment III,
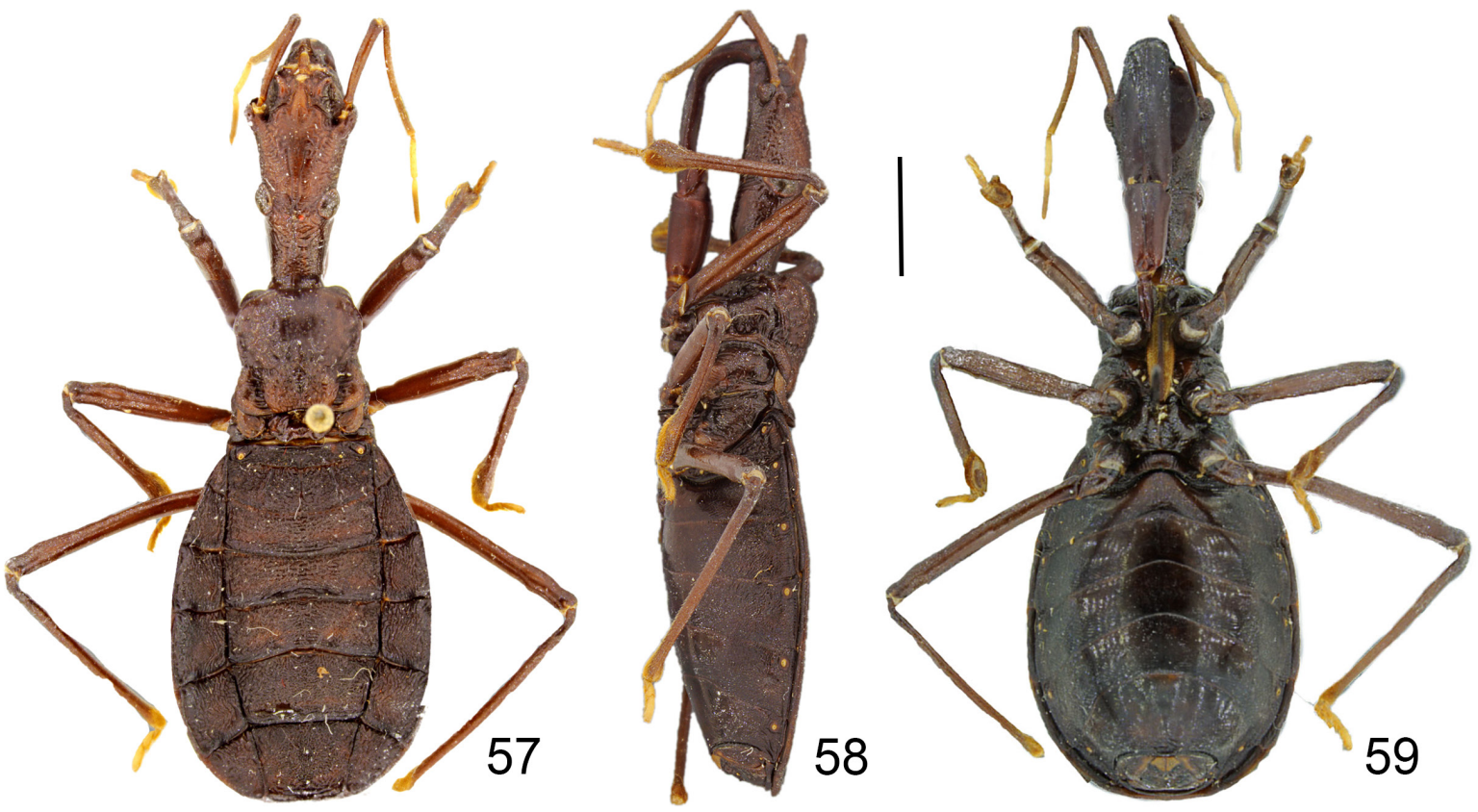

Figs 57-59. Xenorhyncocoris schoenitzeri Putshkov \& Bérenger, 1999, holotype, ㅇ (ZSM), habitus. 57. Dorsal view. 58. Lateral view. 59. Ventral view. Scale bar $=5.00 \mathrm{~mm}$. Photographed by Lars Hendrich, (C) ZSM. 
reaching posterior margin of eye, nearly straight, apically bulbous (Fig. 58); pronotum as broad as its length, anterior lobe strongly swollen, posterior lobe as broad as width of anterior lobe; prosternum reaching middle of mid coxae; scutellum (Fig. 57) suberect; fore wing (Fig. 57) reaching apical $2 / 3$ of scutellum.

\section{Material examined}

Holotype

INDONESIA • + ; West Sumatra, Batang-Palupuh; $0.24602^{\circ} \mathrm{S}, 100.34805^{\circ}$ E; $1400-1500 \mathrm{~m}$ a.s.1.; 19 Oct. 1991; A. Riedel leg.; ZSM.

\section{Remarks}

Putshkov \& Bérenger (1999) described X. schoenitzeri based on a single female specimen from western Sumatra. This specimen is now deposited in the Zoologische Staatssammlung München, Munich, Germany (ZSM). Xenorhyncocoris schoenitzeri is highly recognizable due to its straight and apically bulbous labial segment II, and also by the combination of other characters mentioned in the diagnosis. This species was relatively well documented in its original description and illustrations. Photographs of habitus of the holotype (Figs 57-59) are provided herein to facilitate the recognization of this species. Some diagnostic characters mentioned by Putshkov \& Bérenger (1999) are discussed below.

\section{Distribution}

Indonesia (West Sumatra: Batang-Palupuh).

\section{Discussion}

\section{Discovery of male Xenorhyncocoris}

During our recent field expeditions in Sabah, northeastern Borneo, one female specimen of an undescribed species of Xenorhyncocoris and two distinct male ectrichodiine specimens were collected

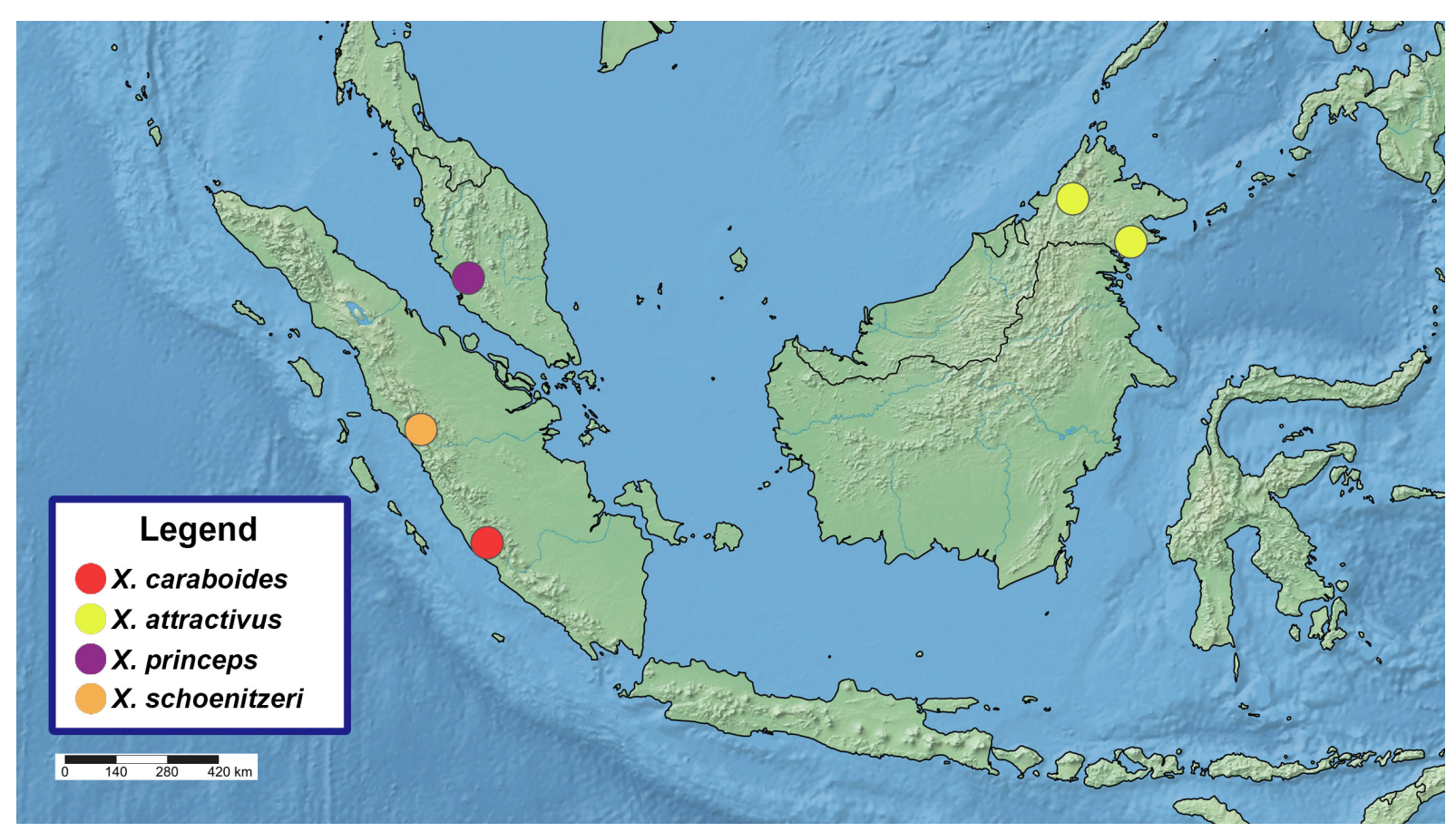

Fig. 60. Distribution of Xenorhyncocoris Miller, 1938. 
from the rainforest on Mt Trus Madi. The male specimens are large-sized, macropterous, and lookvery special among Oriental Ectrichodiini. However, the male specimens present some morphological features (i.e., the elongate and subapically widened head, the four-segmented antennae, the shape of labium and the produced prosternum) that match them to the female specimen, which has the typical Xenorhyncocoris habitus. In order to further determine the species relationship between them, the COI barcode fragment of the female specimen and one of the two male specimens was sequenced. Molecular data unambiguously linked the male with the female specimen, their sequenced $C O I$ fragments being exactly the same. An additional male specimen from Tawau Hills Park in Sabah was subsequently obtained. Despite the certain distance between these two localities, no differences could be found in their morphology; thus we considered it conspecific with the males from Mt Trus Madi. We here describe this species as $X$. attractivus sp. nov., making it the first Xenorhyncocoris species that is known from both male and female specimens.

With the discovery of X. attractivus sp. nov., the genus Xenorhyncocoris is recorded from Borneo for the first time, and the generic distribution range is largely extended (Fig. 60). The male specimens (Fig. 44) from Mt Trus Madi were collected using light traps located in the tropical rainforest, at $\sim 1200 \mathrm{~m}$ above sea level. The single female specimen (Fig. 45) was collected at the same locality, but in different season. The female can make an extremely painful bite (W. Zhang, pers. com.).

\section{On some morphological characters of Xenorhyncocoris}

When firstly describing the genus Xenorhyncocoris, Miller (1938) noticed the specialized labium of $X$. caraboides, which let him to choose such a generic name. Putshkov \& Bérenger (1999) summarized and discussed some diagnostic characters of Xenorhyncocoris. Since the male of Xenorhyncocoris was unknown previously, above studies were all based on female specimens. With the discovery of the male of $X$. attractivus sp. nov., the diagnosis of the genus should be revised to allow recognition of macropterous male and micropterous female as well. Some morphological characters of Xenorhyncocoris are discussed below.

\section{Elongated head}

The head of Xenorhyncocoris is distinctly longer than the pronotum, and widened between the antenniferous tubercles. In macropterous male, the head is 1.35 times as long as the pronotum, the width across eyes is broader than that between the antenniferous tubercles (Figs 18-20). In micropterous female, the head is 1.8-2.2 times as long as the pronotum, the width across eyes is much narrower than that between the antenniferous tubercles due to the reduction of the eye (Figs 5-8, 37-40, 50-53, 57-59). These differences are considered as sexual dimorphism. Additionally, Putshkov \& Bérenger (1999) documented that the head of Xenorhyncocoris lacks the interocular furrow and the delimitation of the neck. The overall shape of the head, as mentioned by Putshkov \& Bérenger (1999), is similar to the semiaquatic Hydrometridae Billberg, 1820, and is quite unique among Ectrichodiini, even clearly different from other head-elongated genera mentioned by Weirauch et al. (2009).

\section{Modified labium}

The labium is extremely distinctive in Xenorhyncocoris and provides a diagnostic feature to the genus. The labial segment II is the longest, basally curved, dorsoventrally flattened, straight or dorsally curved. The labial segment III is distinctly inflated, basally embed into the apex of segment II, forming a movable articulation which allows the up and down movement of the apical two segments. The labial segment IV is tapering, with both sides strongly flattened, thus knife-like. Such modified labium may play an important role in prey capture. Potential preys of species of Xenorhyncocoris may be some large-sized diplopods which have glabrous, cylindrical and strongly sclerotized body. Members of Xenorhyncocoris probably adopt a 'forwardly pointed' feeding posture with their robust labium stretched forwardly, and the elongated head and labium can expand hunting range. The sharp segment IV may facilitate 
penetration into prey body. Additionally, the relatively slender, unarmed fore and mid legs and the small fossula spongiosa also indicate that legs have little effect on predation. The exact functional morphology of the specialized labium and the biology of species of Xenorhyncocoris require future studies.

\section{Characters related to micropterism and sexual dimorphism}

The general habitus of the macropterous male and micropterous female is quite dissimilar, and there are several differences in the vestiture of antennae, the shape of head, thorax and abdomen, and the development of eyes and ocelli. These characters are usually strongly affected by wing polymorphism and are herein treated as sexual dimorphism. Similar differences have been reported in many other ectrichodiine genera (e.g., Dougherty 1995; Rédei \& Tsai 2012; Forthman et al. 2016). The male has well-developed eyes and ocelli, while in female they are moderately to strongly reduced. Miller (1949) reported the small, indistinct ocelli in $X$. princeps but did not show this character in his illustrations. Putshkov \& Bérenger (1999) documented the presence of ocelli in X. schoenitzeri. After our examinations of the female specimens of Xenorhyncocoris, it can be declared that although the ocelli are strongly reduced in the female, the ocellar lens are clearly visible (even in X. caraboides) but probably not functional. Therefore, the presence or absence of ocellar lens, which was utilized as a species level diagnostic character by Putshkov \& Bérenger (1999), is removed from our revised key.

\section{Systematic relationships of Xenorhyncocoris}

The previously known female specimens of Xenorhyncocoris are highly morphologically modified, exhibiting a unique habitus among Ectrichodiini; thus it is difficult to speculate the systematic relationships of the genus. Miller (1938) thought Xenorhyncocoris was closely related to "Physorhynchus auct." (= Haematorrhophus Stål, 1874) because of their similar relative size of pro-, meso- and metathoraxes, and the similar abdomen shape. However, these characters are strongly affected by micropterism. In contrast with Xenorhyncocoris, members of Haematorrhophus have the six-segmented antennae, the thickened femora with tubercles beneath and some additional differentiating characters, indicating that these two genera are probably not phylogenetically related. The newly discovered macropterous male of Xenorhyncocoris provides several characters that differentiate it from the micropterous female, which may have phylogenetic implications.

The general habitus of male of Xenorhyncocoris resembles that of members of Vilius Stål, 1863. The following shared characters of Xenorhyncocoris and Vilius may suggest a close phylogenetic relationship of the two genera: antenniferous tubercle surrounded by process laterally; antennae four-segmented, with the ratio II > I >> IV > III; scutellum broad, with 1+1 lateral prongs and 1+1 widely separated apical prongs; legs slender, without spine or denticle. The four-segmented antenna with the extremely short basiflagellomere is very special. This character has not been reported from any other genus of Ectrichodiini. It may be a potential autapomorphy of this clade. Xenorhyncocoris, however, can be clearly distinguished from Vilius by the elongated head (vs head broad, shorter than pronotum in Vilius), the modified labium (vs labium short, slender, with the ratio III $>$ II $\approx$ IV), and the posteriorly produced prosternum (vs at most slightly surpassing fore coxae in Vilius). Additional differences between Xenorhyncocoris and Vilius are the erect setae on basal two antennal segments shorter than diameter of respective segment (vs setae much longer than diameter of respective segment in Vilius) and the wrinkled posterior pronotal lobe (vs usually smooth in Vilius). Based on these characters, the genus Xenorhyncocoris is recognized as distinct, and it is potentially the sister group of the genus Vilius.

Distant (1902) recognized Schottus Distant, 1902 as an allied genus to Vilius, from which it can be distinguished by the flattened antennal pedicel and the ratio of labial segments. Subsequently, Distant (1919) described the genus Neozirta Distant, 1919 and thought it was perhaps related to the Neotropical genus Zirta Stål, 1859. These two genera have the lamelliform process surrounding the antennal insertion, the four-segmented antennae, the relatively broad scutellum and the simple and unarmed legs; 
therefore they may be closely related to Xenorhyncocoris and Vilius. Moreover, Neozirta and Schottus share the following characters which indicate their potential sister-group relationship, and also differ them from Xenorhyncocoris and Vilius: the antennal segment ratio II $>>$ III $>$ I $>$ IV, the labial segment ratio II $\approx$ III $>$ IV, and the scutellum with the lateral prongs angular or even reduced.

In the recent total-evidence phylogenetic study of Ectrichodiinae (Forthman \& Weirauch 2017), the genera Vilius and Schottus formed sister-group relationship, and exhibited high affinities with the genera Schuhella Dougherty, 1995 and Zirta, indicating that these genera with four-segmented antennae may be phylogenetically closely related, and the above speculations about the relationships among Xenorhyncocoris, Vilius, Neozirta and Schottus are possible. However, Xenorhyncocoris and Neozirta are not sampled in that study, and the genera Vilius, Neozirta and Schottus are taxonomically unrevised, requiring future researches to investigate the true systematic relationships among these genera.

\section{Acknowledgments}

We sincerely thank Dr Lars Hendrich (Zoologische Staatssammlung München, Munich) for providing photographs of holotype of $X$. schoenitzeri. We are grateful to Mr Mick Webb and Ms Valerie A. Lemaître (The Natural History Museum, London) for their kind help with the examination of Reduviidae specimens. We also appreciate Dr Nesrine Akkari (Naturhistorisches Museum Wien, Vienna) and an anonymous reviewer for helpful comments and critical reading of the manuscript. This work was supported by a grant from the National Natural Science Foundation of China (No. 31730086).

\section{References}

Amyot C.J.-B. \& Audinet-Serville J.G. 1843. Histoire naturelle des Insects. Hémiptères. Librairie encyclopédique de Roret, Paris. https://doi.org/10.5962/bhl.title.8471

Cook M.L. 1977. A key to the genera of Asian Ectrichodiinae (Hemiptera: Reduviidae) together with a check-list of genera and species. Oriental Insects 11: 63-88.

https://doi.org/10.1080/00305316.1977.10432084

Distant W.L. 1902. XLI. Rhynchotal notes. XV. Heteroptera: Family Reduviidae (continued), Piratinae and Ectrichodinae. Annals and Magazine of Natural History 10: 282-295.

https://doi.org/10.1080/00222930208678673

Distant W.L. 1919. The Heteroptera of Indo-China. The Entomologist 52: 145-149.

Dougherty V. 1995. A review of the New World Ectrichodiinae genera (Hemiptera: Reduviidae). Transactions of the American Entomological Society 121: 173-225.

Folmer O., Black M., Hoeh W., Lutz R. \& Vrijenhoek R. 1994. DNA primers for amplification of mitochondrial cytochrome c oxidase subunit I from diverse metazoan invertebrates. Molecular Marine Biology and Biotechnology 3: 294-299.

Forthman M. \& Weirauch C. 2012. Toxic associations: A review of the predatory behaviors of millipede assassin bugs (Hemiptera: Reduviidae: Ectrichodiinae). European Journal of Entomology 109: 147153. https://doi.org/10.14411/eje.2012.019

Forthman M. \& Weirauch C. 2017. Millipede assassins and allies (Heteroptera: Reduviidae: Ectrichodiinae, Tribelocephalinae): total evidence phylogeny, revised classification and evolution of sexual dimorphism. Systematic Entomology 42: 575-595. https://doi.org/10.1111/syen.12232

Forthman M. \& Weirauch C. 2018. Phylogenetic comparative analysis supports aposematic colourationbody size association in millipede assassins (Hemiptera: Reduviidae: Ectrichodiinae). Journal of Evolutionary Biology 31: 1071-1078. https://doi.org/10.1111/jeb.13288 
Forthman M., Chłond D. \& Weirauch C. 2016. Taxonomic monograph of the endemic millipede assassin bug fauna of Madagascar (Hemiptera: Reduviidae: Ectrichodiinae). Bulletin of the American Museum of Natural History 400: 1-152. https://doi.org/10.1206/amnb-928-00-01.1

Kumar S., Stecher G. \& Tamura K. 2016. MEGA7: molecular evolutionary genetics analysis version 7.0 for bigger datasets. Molecular Biology and Evolution 33: 1870-1874.

https://doi.org/10.1093/molbev/msw054

Li H., Liu H., Shi A., Štys P., Zhou X. \& Cai W. 2012. The complete mitochondrial genome and novel gene arrangement of the unique-headed bug Stenopirates sp. (Hemiptera: Enicocephalidae). PLoS ONE 7: e29419. https://doi.org/10.1371/journal.pone.0029419

Maldonado Capriles J. 1990. Systematic Catalogue of the Reduviidae of the World (Insecta: Heteroptera). A special edition of Caribbean Journal of Science, Mayagüez.

Miller N.C.E. 1938. A new genus and species of Sumatran Reduviidae (Rhynchota). Proceedings of the Royal Entomological Society of London, Series B 7: 135-136.

https://doi.org/10.1111/j.1365-3113.1938.tb01266.x

Miller N.C.E. 1949. A new genus and new species of Malaysian Reduviidae (Hemiptera). Proceedings of the Royal Entomological Society of London, Series B 18: 229-237.

https://doi.org/10.1111/j.1365-3113.1949.tb01417.x

Putshkov P.V. \& Bérenger J.-M. 1999. Xenorhyncocoris schoenitzeri, nouvelle espèce d'Ectrichodiinae de Sumatra (Heteroptera, Reduviidae). Nouvelle Revue d'Entomologie, New Series 16: 89-93.

Rédei D. \& Tsai J.F. 2012. The assassin bug genus Haematoloecha in Taiwan, with notes on species occurring in the neighbouring areas (Hemiptera: Heteroptera: Reduviidae: Ectrichodiinae). Zootaxa 3332: 1-26. https://doi.org/10.11646/zootaxa.3332.1.1

Rédei D., Ren S. \& Bu W. 2012. A new synonymy in the genus Rhysostethus (Hemiptera: Heteroptera: Reduviidae). Acta Entomologica Musei Nationalis Pragae 52: 341-348.

Schuh R.T., Weirauch C. \& Wheeler W.C. 2009. Phylogenetic relationships within the Cimicomorpha (Hemiptera: Heteroptera): a total-evidence analysis. Systematic Entomology 34: 15-48.

https://doi.org/10.1111/j.1365-3113.2008.00436.x

Shorthouse D.P. 2010. SimpleMappr, an online tool to produce publication-quality point maps. Available from https://www.simplemappr.net [accessed 7 May 2020].

Swanson D.R. 2019. Australian millipede assassins (Heteroptera: Reduviidae): Malingeus tumidus gen. et sp. nov. and Yaramayahus rufescens gen. et sp. nov., with new generic synonyms and an updated key. Austral Entomology 58: 498-514. https://doi.org/10.1111/aen.12413

Weirauch C. 2008a. Cladistic analysis of Reduviidae (Heteroptera: Cimicomorpha) based on morphological characters. Systematic Entomology 33: 229-274.

https://doi.org/10.1111/j.1365-3113.2007.00417.x

Weirauch C. 2008b. From four- to three-segmented labium in Reduviidae (Hemiptera: Heteroptera). Acta Entomologica Musei Nationalis Pragae 48: 331-344.

Weirauch C., Rabitsch W. \& Rédei D. 2009. Austrokatanga, gen. nov., new genus of Ectrichodiinae (Hemiptera: Heteroptera: Reduviidae) from Australia. Zootaxa 2094: 1-15.

https://doi.org/10.11646/zootaxa.2094.1.1

Weirauch C., Bérenger J.-M., Berniker L., Forero D., Forthman M., Frankenberg S., Freedman A., Gordon E., Hoey-Chamberlain R., Hwang W.S., Marshall S.A., Michael A., Paiero S.M., Udah O., Watson C., Yeo M., Zhang G. \& Zhang J. 2014. An illustrated identification key to assassin bug 
subfamilies and tribes (Hemiptera: Reduviidae). Canadian Journal of Arthropod Identification 26: 1-115. https://doi.org/10.3752/cjai.2014.26

Weirauch C., Forthman M., Grebennikov V. \& Baňař P. 2017. From Eastern Arc Mountains to extreme sexual dimorphism: systematics of the enigmatic assassin bug genus Xenocaucus (Hemiptera: Reduviidae: Tribelocephalinae). Organisms Diversity \& Evolution 17: 421-445.

https://doi.org/10.1007/s13127-016-0314-2

Zhang G. \& Weirauch C. 2011. Matching dimorphic sexes and immature stages with adults: resolving the systematics of the Bekilya group of Malagasy assassin bugs (Hemiptera: Reduviidae: Peiratinae). Systematic Entomology 36: 115-138. https://doi.org/10.1111/j.1365-3113.2010.00551.x

Manuscript received: 28 July 2020

Manuscript accepted: 9 February 2021

Published on: 16 April 2021

Topic editor: Nesrine Akkari

Desk editor: Radka Rosenbaumová

Printed versions of all papers are also deposited in the libraries of the institutes that are members of the EJT consortium: Muséum national d'histoire naturelle, Paris, France; Meise Botanic Garden, Belgium; Royal Museum for Central Africa, Tervuren, Belgium; Royal Belgian Institute of Natural Sciences, Brussels, Belgium; Natural History Museum of Denmark, Copenhagen, Denmark; Naturalis Biodiversity Center, Leiden, the Netherlands; Museo Nacional de Ciencias Naturales-CSIC, Madrid, Spain; Real Jardín Botánico de Madrid CSIC, Spain; Zoological Research Museum Alexander Koenig, Bonn, Germany; National Museum, Prague, Czech Republic. 